\title{
Lessons from Rwanda
}

Vishanthie Sewpaul

Senior Professor

School of Social Work \& Community Development UKZN 
$\mathrm{B}$ efore a recent visit to Rwanda, all that the country held for me, as with most people, was the spectre of genocide, war, poverty and starving children. My brief visit to the city of Kigali challenged my widely held assumptions about the country. Kigali was the epicenter of the genocide in Rwanda, where about one million people experienced murderous tyranny within a space of 100 days, that wreaked havoc upon the country and left millions of people with untold losses and emotional scars. Rwanda is, indeed, an amazing example of a country rising from the ashes. My first encounter was on the Air Rwanda flight, where the in-flight magazine warns those entering the country to leave their plastic bags behind; that no person would be allowed to pass through immigration and customs with plastic bags and wrappings. A plastic bag free country is one of Rwanda's contributions to environmental conservation and saving the earth. And of course in stores, its paper bags all the way!

In Kigali I was struck by the cleanliness of the place; littering is certainly not the order of the day. I walked on the streets through the city centre and on its periphery, thinking that its very cleanliness would generate fear about throwing a matchstick or a piece of paper on the ground. I could not help but contrast this with the city of Durban, strewn, especially after the street vendors have left, with paper and unwanted fruit, vegetables and packaging. Kigali has several roundabouts that are so beautifully maintained with trees, flowers and lawns that it reminded me of the manicured gardens of Sentosa Island in Singapore. And to top it all I was assured of my safely, even when walking alone on the streets. It was a relief to read the local daily paper and not come across stories of rape, murder and theft, an evident contrast with South Africa. It is unfortunate that I do not enjoy such safety in my own city. With housebreaking and theft, which my family was a victim of, we are afraid even within the confines of our own homes. Yet, South Africa boasts being the most developed country among the Southern African countries! If poverty is a precursor to crime, HIV/AIDS and various social ills and with Rwanda being a far poorer country than South Africa, we need to ask: What might Rwanda be doing right that South Africa can learn from?" Ironically, while South Africa was going through its most emancipatory phase in history, Rwanda was experiencing its worse oppression and nightmare in April 1994.

For an outsider, making a brief visit to the city I became aware of the sense of civic responsibility among people, a culture and message that seems to be reinforced at different levels of Rwandan society. On entering the hotel bathroom, I noted a message saying that condoms were provided free of charge in the bedside drawer for the convenience and protection of guests. Is it that in taking care of "others" (guests) Rwanda takes care of its own as well? It's hardly likely that at a rate of US\$ 155 per night, regular Rwandese would be the hotel's patrons. And on the information stand in the room, there was a bold warning that child tourism sex is a criminal offence. The warning, spoke to the opportunities offered in travelling to engage in such illicit sex, as guests remain fairly anonymous. It warned about both the immorality and illegality of sex with minors and exhorted people to join hands in fighting crime against vulnerable children. This was yet another message of the level of social awareness and consciousness of the Rwandese. On the streets there are huge bill boards, in the local language, warning about HIV/AIDS with adverts for condoms.

On enquiring about the marked cleanliness of the city, I was informed and later read about the once per month community service day! The last Saturday of every month is declared community service day, when every adult Rwandese is expected to engage in activities to uplift their communities. These activities, that are coordinated at local government level, include e.g. planting trees, flowers and grass, building and unblocking sewers. Citizens take their identity books and register on reporting for each community service day. No capable adult is exempt from this. I was told that the President gets onto the grounds, with hoe in hand and digs alongside citizens; he leads by example. Apart from contributing to infrastructural development (despite the devastation of the genocide Kigali has quite well developed infrastructure and buildings), community service, contributes to relationship building among 
the different ethnic groups. (Differentiating between Tutsis and Hutus constitutes a criminal offence as Rwanda pledges to "Genocide: Never Again!" and in its efforts to consolidate a common Rwandese identity). As people work together, they talk, and the day usually ends with sharing a meal and drinks. This ethos of community service and instilling pride in the country extends into the private sphere. Residential areas are divided into cells, with an overseer, paid by the government, for each cell. Each household is expected to plant trees and flowers and maintain their private spaces in ways that are aesthetically appealing.

I had the opportunity to interview a social worker at an International Non-governmental Organization who works with the Garcaca Courts. The Garcaca are community based courts, derived from tribal systems of justice that used to deal with issues regarding minor family disputes, cattle theft and so on. After the genocide, there was (and is) no capacity within the criminal justice system to deal with all the perpetrators of the genocide; neither is there capacity within this system to hear all the victims of genocide. The tribal system was adopted, with training of the local elders who preside over the courts, to ascertain the guilt or innocence of alleged perpetrators, and who determine sentencing. The courts also allow for voluntary submissions from perpetrators in their pursuit of amnesty. Social workers play an important role in these courts providing an oversight function; ensuring that the hearings are fair and impartial, securing legal assistance for alleged perpetrators and victims where necessary, and on-site debriefing and support for victims as the hearings engender a great deal of emotional trauma. While the Garcaca courts are, by no means, a perfect solution and leaves a lot to be desired, under the circumstances the Rwandese are doing the best that they can with what they have. Perhaps, one of the most important functions that the Garcaca courts serve is that it allows for victims' feelings and experiences to be heard and validated within local communities on an on-going basis. This is a necessary and important part of healing, and one that perhaps South Africa can emulate. The racial oppression, atrocities, anger and hate engendered during apartheid cannot be swept away. We need to create safe spaces to talk about "race" and racism, and allow spaces for people to work through hurt, anger, anguish and the often, all too diminished sense of self that apartheid has left the majority of South Africa's people with ... historical oppression is very much part of our present. Internalised oppression, a deep dynamic carried into the present by the majority of South Africans, manifests in diverse ways, one of which is perhaps the tendency to confuse servitude with service. We need to understand that service is in the interest of each one of us and in the interest of the country as a whole. 